\title{
Quantitative analysis of the berry size in grapevine cultivar 'Italia' • Digital image analysis of the grapevine
}

E. SOMOGYI ${ }^{1}$, Á. KUN² ${ }^{2}$ J. LÁZÁR ${ }^{1}$, P. BODOR-PESTI ${ }^{1 *}$ (1) and D. Á. NYITRAINÉ SÁRDY ${ }^{1}$

${ }^{1}$ Institute of Viticulture and Enology, Hungarian University of Agriculture and Life Sciences, Villányi str. 29-43, 1118 Budapest, Hungary

${ }^{2}$ Kun Szőlő Nursery and Table Grape, Kővágótöttös, Hungary

\section{CONFERENCE FULL PAPER}

Received: June 8, 2021 • Accepted: August 2, 2021

Published online: August 26, 2021

(c) 2021 The Author(s)

\begin{abstract}
Quantitative evaluation of the horticultural crops has high importance to identify cultivars, describe the effect of the growing location and cultivation technology or define consumer's preference regarding the size and shape. Fruit traits of the grapevine (Vitis vinifera L.) are mainly described by the bunch and berry morphology notably bunch and berry size, weight and shape. Ampelographers particularly evaluate the berry based on the seed number as it influences size and consumers' decision. In this study, berry morphological traits of the grapevine cultivar 'Italia' was investigated based on digital image analysis. Samples were collected from two vineyards in Hungary with different ecological and cultivation circumstances. Altogether 12 traits were investigated: weight, seed number, size and shape attributes. Results showed that berry morphological traits - except from the shape attributes - are not differing between the two sampling locations. In accordance with previous studies, seed number - ranging from 0 to 4 - had noticeable effect on the size attributes.
\end{abstract}

\section{KEYWORDS}

uvometry, fruit size variance, berry shape, image analysis

*Corresponding author. E-mail: Bodor-Pesti.Peter@uni-mate.hu 


\section{INTRODUCTION}

Vegetable and fruit species have numerous quality parameters, and consumers are mainly affected by the size, the typical colour and the shape (Predieri et al., 2004). Grapevine (Vitis vinifera L.) is one of the most important horticultural crops where appearance, for example bunch size and compactness, berry size, shape and colour highly influence the table grape consumers' decision. Description of the berry size already appeared in literature in the $16^{\text {th }}$ century. Szikszai (1590) mentioned 'uva spionia' ('nagyszemü szölö' = large-berried grape). Parkinson (1629) introduced 'small blacke grape', which, according to the illustration, referred to the berry size. Duhamel (1768) described many cultivars in his book: Traité des arbres fruitiers for example 'Chasselas doré, 'Muscat blanc' and 'Cornichon blanc'. The colourful paintings showed divers berry shapes and sizes and in some cases, parthenocarpy-like berries are possible to identify in the figures, which is a widely investigated phenomenon in grapevine and causes divers berry sizes within bunches. Today both ampelographic literatures (Barbagallo et al., 2011) and official descriptors, as the descriptor list of the International Organisation of Vine and Wine (OIV) detail berry size classes (OIV, 2009), which are measured for example with ruler (Frege, 1804), with calliper (Kircherer et al., 2013) or with digital image analysis (Roscher et al., 2014). There are several image analysis software dealing with mostly the size of different parts of horticultural crops. 'Tomato Analyzer' (TA) for example evaluates the perimeter and the area, the maximum width and height, the width at mid height and the height at mid width also. The program can evaluate different fruit shape indexes, the Fruit shape index external I, which is the ratio of the maximum height and maximum width, and Fruit shape index external II, being the ratio of the height mid width and width mid height. The Proximal fruit blockiness and Distal fruit blockiness show the ratio of the upper (proximal) and the lower (distal) thirds ratios to the width mid height. Furthermore, the asymmetry of the fruit can be described with the help of the software (Rodríguez et al., 2010).

The purpose of this study was to evaluate the berry morphological traits of the grapevine cultivar 'Italia' influenced by the seed number of the berries, and compare samples collected from two different vineyards.

\section{MATERIALS AND METHODS}

Samples of Vitis vinifera L. cv. 'Italia' were collected from the Institute for Viticulture and Oenology of the Hungarian University of Agriculture and Life Sciences (Kecskemét, Hungary) and from the Kun Szőlő Nursery and Table Grape Plantation (Kővágótöttös, Hungary). Ten bunches in full maturity were collected as it is recommended by the International Organisation of Vine and Wine (descriptor: OIV220) (OIV, 2009) and of each bunch 15-15 berries were randomly sampled from the middle third of the bunches. The chosen berries were numbered, and after that pedicels and receptacles were gently removed. Samples were individually weighed on an Ohaus Explorer Pro EP114C analytical balance (Ohause Corporation, Pine Brook, NJ USA), and then the berries were halved. Seeds of the halved berries were then counted and noted. Digitalization of one section per each berry was carried out with Epson V370 scanner (Seico Epson Corporation, Japan) at 200 dpi. TIFF images were then analysed with the 'Tomato Analyser' (TA) software according to the protocol reported by Brewer et al. (2006). In this study, 
10 traits were evaluated with the 'Tomato Analyzer' as basic measurements (Perimeter, Area, Width Mid-height, Maximum Width, Height Mid-width, Maximum Height, Curved Height), fruit shape indexes (Fruit Shape Index External I, Fruit Shape Index External II, Curved Fruit Shape Index). Detailed description of the investigated traits are introduced in Hurtado et al. (2013). Statistical analysis of the data: summary statistics and ANOVA was carried out with the PAST (Hammer et al., 2001) software.

\section{RESULTS}

Morphological characteristics of the grapevine cultivar 'Italia' in different locations: Results showed that in the case of the investigated size traits there were no significant differences of the values of the two locations. Seed numbers of the berries were similar (Table 1). Berries with one seed were the most frequent in Kecskemét and Kövágótöttös with $37.16 \%$ and $38 \%$, respectively, while the 4 -seeded berries were the less frequent with $4.05 \%$ and $2.67 \%$. The mean berry weight was $6.13 \mathrm{~g}$, while the mean value of the samples of Kecskemét was $5.98 \mathrm{~g}$ and $6.29 \mathrm{~g}$ of Kővágótöttös (Table 2). The mean value of perimeter was $77.18 \mathrm{~mm}, 77.64 \mathrm{~mm}$ of Kecskemét and $76.78 \mathrm{~mm}$ of Kövágótöttös. There were differences yet not significant in the case of the area, the mean value was $416.72 \mathrm{~mm}^{2}$, the mean of Kecskemét's representatives was 418.1 and $415.78 \mathrm{~mm}^{2}$ those of Kövágótőttös. The average values of Width mid-height and Maximum width were very similar (WMH: $20.87 \mathrm{~mm}$, MW: $21.18 \mathrm{~mm}$ ), furthermore in the case of Kecskemét and Kövágótöttös there was no dissimilarity of the two traits either. The mean of Height Mid-width was $24.35 \mathrm{~mm}$, while the average of Kecskemét valued $24.73 \mathrm{~mm}$ and Kóvágótöttös's was $24 \mathrm{~mm}$. The Maximum Height of the samples was $24.95 \mathrm{~mm}$ in average, and it was $25.44 \mathrm{~mm}$ and $24.55 \mathrm{~mm}$ of the two different locations. The mean of Curved Height was $28.08 \mathrm{~mm}$, and the two locations had $28.57 \mathrm{~mm}$ and $27.62 \mathrm{~mm}$ in average. On the other hand, the examined shape traits, namely Fruit Shape Index External I and II had significant differences according to the growing sites, the mean value of Fruit Shape Index External I was 1.15, while that of Fruit Shape Index External II was 1.17. The average of the samples of Kecskemét was 1.21 and 1.2, while they were 1.15 and 1.14 of the Kővágótöttös's values. The growing sites had no significant effects on the samples in the case of the third investigated shape trait. The mean value of the Curved Fruit Shape Index was 1.33, Kecskemét valued 1.37, while Kövágótöttös's average was 1.3.

The effect of the seed number on the morphological traits: Results showed that the investigated samples had 0 to 4 seeds per berry. Seedlessness was present in $6.04 \%$ of the samples while four seeds were also rare (3.35\%). Most berries had one or two seeds $(37.58 \%$ and $33.89 \%$ of the sample set respectively). Data showed that seed number had significant effect on the size and

Table 1. Frequency of berries with different seed numbers in the two investigated locations

\begin{tabular}{lcc}
\hline Seed number per berry & Kecskemét & Kövágótöttös \\
\hline 0 & $7.43 \%$ & $4.67 \%$ \\
1 & $37.16 \%$ & $38 \%$ \\
2 & $31.76 \%$ & $36 \%$ \\
3 & $19.59 \%$ & $18.67 \%$ \\
4 & $4.05 \%$ & $2.67 \%$ \\
\hline
\end{tabular}


Table 2. Summary statistics of the berry morphological traits in the two investigated locations

\begin{tabular}{|c|c|c|c|c|c|c|}
\hline Morphological trait & Location & Mean & Min. & Max. & Stand. dev. & Coeff. var. \\
\hline \multicolumn{7}{|l|}{ Size traits } \\
\hline \multirow[t]{2}{*}{ Weight } & Kecskemét & $5.98^{\mathrm{a}}$ & 1.09 & 9.9 & 1.7 & 28.36 \\
\hline & Kővágótöttös & $6.29^{\mathrm{a}}$ & 1.7 & 11.16 & 1.87 & 29.8 \\
\hline \multirow[t]{2}{*}{ Perimeter } & Kecskemét & $77.64^{\mathrm{a}}$ & 55.5 & 94.8 & 7.39 & 9.52 \\
\hline & Kővágótöttös & $76.78^{\mathrm{a}}$ & 56.07 & 95.74 & 7.77 & 10.12 \\
\hline \multirow[t]{2}{*}{ Area } & Kecskemét & $418.1^{\mathrm{a}}$ & 216.64 & 588.63 & 77.4 & 18.51 \\
\hline & Kővágótöttös & $415.78^{\mathrm{a}}$ & 226.61 & 593.64 & 78.52 & 18.88 \\
\hline \multirow[t]{2}{*}{ Width Mid-height } & Kecskemét & $20.68^{\mathrm{a}}$ & 14.86 & 25.02 & 2.12 & 10.23 \\
\hline & Kővágótöttös & $21.07^{\mathrm{a}}$ & 14.86 & 27.69 & 2.24 & 10.62 \\
\hline \multirow[t]{2}{*}{ Maximum Width } & Kecskemét & $21^{\mathrm{a}}$ & 15.11 & 25.15 & 2.07 & 9.84 \\
\hline & Kővágótöttös & $21.36^{\mathrm{a}}$ & 15.24 & 27.69 & 2.16 & 10.13 \\
\hline \multirow[t]{2}{*}{ Height Mid-width } & Kecskemét & $24.73^{\mathrm{a}}$ & 16.38 & 30.73 & 2.9 & 11.75 \\
\hline & Kővágótöttös & $24^{\mathrm{a}}$ & 15.75 & 31.62 & 2.79 & 11.64 \\
\hline \multirow[t]{2}{*}{ Maximum Height } & Kecskemét & $25.44^{\mathrm{a}}$ & 18.54 & 30.73 & 2.36 & 9.28 \\
\hline & Kővágótöttös & $24.55^{\mathrm{a}}$ & 17.91 & 31.75 & 2.56 & 10.42 \\
\hline \multirow[t]{2}{*}{ Curved Height } & Kecskemét & $28.57^{\mathrm{a}}$ & 20.85 & 35.43 & 2.81 & 9.83 \\
\hline & Kővágótöttös & $27.62^{\mathrm{a}}$ & 19.22 & 36.2 & 3.11 & 11.25 \\
\hline \multicolumn{7}{|l|}{ Shape traits } \\
\hline \multirow[t]{2}{*}{ Fruit Shape Index External I } & Kecskemét & $1.21^{\mathrm{b}}$ & 1.03 & 1.4 & 0.08 & 6.35 \\
\hline & Kővágótöttös & $1.15^{\mathrm{a}}$ & 0.96 & 1.45 & 0.09 & 7.97 \\
\hline \multirow[t]{2}{*}{ Fruit Shape Index External II } & Kecskemét & $1.2^{\mathrm{b}}$ & 0.86 & 1.4 & 0.09 & 7.92 \\
\hline & Kővágótöttös & $1.14^{\mathrm{a}}$ & 0.83 & 1.49 & 0.11 & 9.68 \\
\hline \multirow{2}{*}{ Curved Fruit Shape Index } & Kecskemét & $1.37^{\mathrm{a}}$ & 1.15 & 1.64 & 0.1 & 7.5 \\
\hline & Kővágótöttös & $1.3^{\mathrm{a}}$ & 1.05 & 1.67 & 0.11 & 8.17 \\
\hline
\end{tabular}

Means followed by different letters indicate significant difference $(P<0.05)$.

shape traits of the 'Italia' grapevine cultivar (Table 3). According to the investigation, seed number had significant effect $(P<0.05)$ on the berry weight. Differences were noticeable among the group of berries with different seed numbers except for the three- and four-seeded berries. Smallest berries were the seedless group with $2.8 \mathrm{~g}$ in average, while those with four seeds had $8.01 \mathrm{~g}$. Coefficient of variation was the highest in the case of seedless berries $(38.51 \%)$ meaning that this group was the most divers in weight. The most uniform berry weight was observed in the case of four-seeded berries $(\mathrm{CV}=11.64 \%)$. Size traits showed the same pattern. Perimeter was the smallest in the case of seedless berries $(63.69 \mathrm{~mm})$ while the largest were the four-seeded ones $(84.94 \mathrm{~mm})$. Variability of the perimeter was the highest in the case of seedless berries (CV $=10.05 \%)$ while the lowest $\mathrm{CV}$ value was observed in the case of the four-seeded ones $(\mathrm{CV}=$ $5.6 \%)$. Area of the berries also significantly changed caused by the different seed numbers. Trend in the change was the same as in the case of weight and perimeter. Size was evaluated according to the width and length too. These traits showed the same tendency as above. Lowest values were recorded in the case of seedless berries while the highest values in the case of the four-seeded ones. Variation of the values within each group (CV values) were the lowest in the four-seeded berries while the highest values were recorded in the case of the seedless ones. Shape of the berries were evaluated according to the fruit shape index calculated by the ratio of the width and 
Table 3. Summary statistics of the different seed number groups of the 'Italia' grapevine cultivar

\begin{tabular}{|c|c|c|c|c|c|c|}
\hline Morphological trait & Seed number & Mean & Min. & Max. & Stand. dev. & Coeff. var. \\
\hline \multicolumn{7}{|l|}{ Size traits } \\
\hline \multirow[t]{5}{*}{ Berry weight (g) } & 0 & $2.8^{\mathrm{a}}$ & 1.09 & 5.23 & 1.08 & 38.51 \\
\hline & 1 & $5.14^{\mathrm{b}}$ & 2.45 & 9.46 & 1.08 & 21.09 \\
\hline & 2 & $6.59^{c}$ & 3.4 & 9.67 & 1.09 & 16.56 \\
\hline & 3 & $8^{\mathrm{d}}$ & 4.92 & 11.16 & 1.38 & 17.31 \\
\hline & 4 & $8.01^{\mathrm{d}}$ & 6.17 & 9.41 & 0.93 & 11.64 \\
\hline \multirow[t]{5}{*}{ Perimeter (mm) } & 0 & $63.69^{\mathrm{a}}$ & 55.5 & 74.4 & 6.4 & 10.05 \\
\hline & 1 & $72.51^{b}$ & 59.8 & 95.74 & 6.17 & 8.51 \\
\hline & 2 & $79.34^{c}$ & 63.8 & 93.34 & 5.42 & 6.83 \\
\hline & 3 & $83.56^{\mathrm{d}}$ & 72.69 & 91.9 & 4.67 & 5.59 \\
\hline & 4 & $84.94^{\mathrm{d}}$ & 80.18 & 93.84 & 4.76 & 5.6 \\
\hline \multirow[t]{5}{*}{ Area $\left(\mathrm{mm}^{2}\right)$} & 0 & $274.11^{\mathrm{a}}$ & 216.64 & 387.77 & 53.97 & 19.69 \\
\hline & 1 & $365.82^{\mathrm{b}}$ & 226.61 & 513.55 & 51.94 & 14.2 \\
\hline & 2 & $437.78^{\mathrm{c}}$ & 287.84 & 549.58 & 49.8 & 11.38 \\
\hline & 3 & $495.43^{\mathrm{d}}$ & 375 & 593.64 & 54.96 & 11.09 \\
\hline & 4 & $496.69^{\mathrm{d}}$ & 447.93 & 588.63 & 42.65 & 8.59 \\
\hline \multirow[t]{5}{*}{ Width Mid-height (mm) } & 0 & $17.08^{\mathrm{a}}$ & 14.86 & 19.94 & 1.71 & 10.01 \\
\hline & 1 & $19.6^{\mathrm{b}}$ & 14.86 & 24.51 & 1.69 & 8.6 \\
\hline & 2 & $21.25^{\mathrm{c}}$ & 17.27 & 24.77 & 1.51 & 7.1 \\
\hline & 3 & $23.01^{\mathrm{d}}$ & 19.43 & 27.69 & 1.61 & 7 \\
\hline & 4 & $22.96^{\mathrm{d}}$ & 20.57 & 24.51 & 1.29 & 5.61 \\
\hline \multirow[t]{5}{*}{ Maximum Width (mm) } & 0 & $17.3^{\mathrm{a}}$ & 15.11 & 20.07 & 1.74 & 10.05 \\
\hline & 1 & $19.96^{\mathrm{b}}$ & 15.24 & 24.77 & 1.64 & 8.22 \\
\hline & 2 & $21.57^{\mathrm{c}}$ & 17.65 & 24.77 & 1.46 & 6.77 \\
\hline & 3 & $23.2^{\mathrm{d}}$ & 19.81 & 27.69 & 1.57 & 6.77 \\
\hline & 4 & $23.33^{\mathrm{d}}$ & 21.46 & 24.64 & 1.02 & 4.36 \\
\hline \multirow[t]{5}{*}{ Height Mid-width (mm) } & 0 & $20.08^{\mathrm{a}}$ & 17.91 & 24.51 & 2.09 & 10.42 \\
\hline & 1 & $22.72^{\mathrm{b}}$ & 15.75 & 26.8 & 2.36 & 10.37 \\
\hline & 2 & $25.07^{\mathrm{c}}$ & 16 & 29.46 & 2.37 & 9.47 \\
\hline & 3 & $26.63^{\mathrm{d}}$ & 21.97 & 31.62 & 1.95 & 7.31 \\
\hline & 4 & $26.28^{\mathrm{cd}}$ & 19.05 & 30.23 & 2.92 & 11.11 \\
\hline \multirow[t]{5}{*}{ Maximum Height (mm) } & 0 & $20.61^{\mathrm{a}}$ & 17.91 & 24.64 & 2.1 & 10.19 \\
\hline & 1 & $23.39^{b}$ & 19.18 & 27.94 & 1.89 & 8.1 \\
\hline & 2 & $25.85^{\mathrm{c}}$ & 21.08 & 31.24 & 1.86 & 7.2 \\
\hline & 3 & $26.96^{\mathrm{d}}$ & 22.61 & 31.75 & 1.77 & 6.57 \\
\hline & 4 & $27.13^{\mathrm{cd}}$ & 25.53 & 30.73 & 1.61 & 5.93 \\
\hline \multirow[t]{5}{*}{ Curved Height (mm) } & 0 & $23.16^{\mathrm{a}}$ & 19.22 & 26.58 & 2.48 & 10.71 \\
\hline & 1 & $26.35^{\mathrm{b}}$ & 20.93 & 32.05 & 2.46 & 9.33 \\
\hline & 2 & $28.87^{\mathrm{c}}$ & 23.44 & 34.63 & 2.24 & 7.76 \\
\hline & 3 & $30.57^{\mathrm{d}}$ & 25.09 & 36.2 & 2.2 & 7.18 \\
\hline & 4 & $30.62^{\mathrm{cd}}$ & 28.13 & 33.82 & 2.05 & 6.68 \\
\hline \multicolumn{7}{|l|}{ Shape traits } \\
\hline \multirow[t]{3}{*}{ Fruit Shape Index External I } & 0 & $1.2^{\mathrm{a}}$ & 1.06 & 1.4 & 0.08 & 6.88 \\
\hline & 1 & $1.18^{\mathrm{a}}$ & 0.97 & 1.41 & 0.09 & 7.28 \\
\hline & 2 & $1.2^{\mathrm{a}}$ & 0.99 & 1.45 & 0.1 & $\begin{array}{c}8.01 \\
\text { (continued) }\end{array}$ \\
\hline
\end{tabular}


Table 3. Continued

\begin{tabular}{lcccccc}
\hline Morphological trait & Seed number & Mean & Min. & Max. & Stand. dev. & Coeff. var. \\
\hline \multirow{4}{*}{ Fruit Shape Index External II } & 3 & $1.17^{\mathrm{a}}$ & 0.96 & 1.36 & 0.09 & 7.6 \\
& 4 & $1.16^{\mathrm{a}}$ & 1.09 & 1.28 & 0.06 & 5.21 \\
& 0 & $1.19^{\mathrm{a}}$ & 1.07 & 1.31 & 0.07 & 6.26 \\
& 1 & $1.16^{\mathrm{a}}$ & 0.85 & 1.48 & 0.11 & 9.15 \\
Curved Fruit Shape Index & 2 & $1.18^{\mathrm{a}}$ & 0.83 & 1.49 & 0.12 & 9.93 \\
& 3 & $1.16^{\mathrm{a}}$ & 0.95 & 1.36 & 0.1 & 8.22 \\
& 4 & $1.14^{\mathrm{a}}$ & 0.93 & 1.29 & 0.1 & 8.56 \\
& 0 & $1.33^{\mathrm{a}}$ & 1.11 & 1.58 & 0.12 & 9.27 \\
& 1 & $1.33^{\mathrm{a}}$ & 1.13 & 1.64 & 0.11 & 8.06 \\
& 2 & $1.35^{\mathrm{a}}$ & 1.09 & 1.67 & 0.12 & 8.79 \\
& 3 & $1.32^{\mathrm{a}}$ & 1.05 & 1.57 & 0.1 & 7.68 \\
\hline
\end{tabular}

Means followed by different letters indicate significant difference $(P<0.05)$.

length at different positions of the berries. Low variability was observed in the fruit shape index, CV values ranged from $5.21 \%$ to $9.93 \%$ and there was no significant difference among the samples with different seed numbers.

\section{DISCUSSION}

'Italia' is one of the most important and most studied among the grapevine cultivars. Italia has several somatic mutations resulting new cultivars with variable morphological traits (Maia et al., 2009). Beside these bud sports, a large number of clones are in cultivation. Characterization and discrimination of these sports and clones have high importance (Fanizza et al., 2003), which can be carried out both with morphological and molecular approaches too. There are more than 150 traits in the OIV (2009) descriptor list, within this 20 are dealing with the berry morphology. Size is described by the length and width of the berries, where 5 classes are available for length: very short (up to about $8 \mathrm{~mm}$ ), short (about $13 \mathrm{~mm}$ ), medium (about $18 \mathrm{~mm}$ ), long (about $23 \mathrm{~mm}$ ) and very long (about $28 \mathrm{~mm}$ and more), and for the width too: very narrow (up to about $8 \mathrm{~mm}$ ), narrow (about $13 \mathrm{~mm}$ ), medium (about $18 \mathrm{~mm}$ ), wide (about $23 \mathrm{~mm}$ ) and very wide (about $28 \mathrm{~mm}$ and more). In this study, we found that berry size of the 'Italia' grapevine cultivar ranged from medium to large categories.

Width can be evaluated at various positions of the berry. In the TA, there is a possibility to investigate the width at the half of the height and at the widest position. In the case of 'Italia' we found only minor difference between these data, but berry shape in many cultivars are not spherical, but ellipsoid, obovoid, ovoid or in extreme cases, horn or finger shaped. In the latter categories, size traits measured at different positions can vary significantly. According to this, it would be important to highlight in the reports and descriptor lists at which position the berry width is measured at all.

Grapevine berry size is changing during the development according to a double sigmoid curve. Final size depends on the cultivar (Bényei and Lörincz, 2005), pruning bud-load (Intrieri 
et al., 2001), special canopy management treatments (Carreño et al., 1998) or for example the seed number. Grapevine berry has usually (0) 1 to 4 (5) seeds. In this study, we found that 'Italia' have 0 to 4 seeds in the berries. Authors in the early 18th century were already dealing with the seed number of the cultivars and in some cases highlighted the seedlessness as Miller (1724) mentioned 'the Currant grape is something larger than the former, is a very good fruit has no seeds'. Today this phenomenon is a central aim of the table grape breeding (Royo et al., 2018). In this study, we found that $6.04 \%$ of the samples had no seeds, while most of the berries had 1 or 2 seeds (37.58\% and 33.89\% respectively), which result is in accordance with Sabir (2011), who found that seed number ranges from 1.84 to 1.98 per berry according to the pollinator.

Calculation of the berry size traits provides primary data (width, length), but further data can help to calculate surface area too. Skin surface of the grapevine has high importance to evaluate for example anthocyanin content, which is a key factor of red wine production. Díaz-Pérez et al. (2007) calculated bell pepper skin surface based on photocopy, while Barbagallo et al. (2011) applied a LICOR LI 3100 area meter for the evaluation of the skin surface of Syrah grapevine cultivar. Image analysis of the berry size traits can be a possible way for the skin surface measurements too.

\section{CONCLUSIONS}

Grapevine berry shape and size are traits affected by many factors. Such factors could be environmental or developmental factors. According to this research it can be stated that seed number influences significantly the size of the grapevine berries.

\section{ACKNOWLEDGEMENT}

This research was supported by the Ministry of Innovation and Technology within the framework of the Thematic Excellence Programme 2020, National Challenges Subprogramme (TKP2020-NKA-16) and Institutional Excellence Subprogram (TKP2020-IKA-12) for research on plant breeding and plant protection.

\section{REFERENCES}

Barbagallo, M.G., Guidoni, S., and Hunter J.J. (2011). Berry size and qualitative characteristics of Vitis vinifera L. cv. Syrah. South African Journal of Enology and Viticulture, 32(1): 129-136.

Bényei, F. and Lőrincz, A. (2005). Borszőlöfajták, csemegeszőlö-fajták és alanyok. Mezőgazda Kiadó, Budapest, p. 314.

Brewer, M. T., Lang, L., Fujimura, K., Dujmovic, N., Gray, S., and van der Knaap, E. (2006). Development of a controlled vocabulary and software application to analyze fruit shape variation in tomato and other plant species. Plant Physiology, 141: 15-25.

Carreno, J., Faraj, S., and Martinez, A. (1998). Effects of girdling and covering mesh on ripening, colour and fruit characteristics of 'Italia' grapes. The Journal of Horticultural Science and Biotechnology, 73(1): 103-106. 
Díaz-Pérez, J.C., Muy- Rangel, M.D., and Mascorro, A.G. (2007). Fruit size and stage of ripeness affect postharvest water loss in bell pepper fruit (Capsicum annuum L.). Journal of the Science of Food and Agriculture, 87: 68-73.

Duhamel, du M. (1768). Traité des arbres fruitiers: contenant leur figure, leur description, leur culture, \& c, Vol 2. Paris. 261.

Fanizza, G., Chaabane, R., Ricciardi, L., and Resta, P. (2003). Analysis of a spontaneous mutant and selected clones of cv. Italia (Vitis vinifera) by AFLP markers. Vitis, 42(1): 27-30.

Frege, M.C.A. (1804). Versuch einer Classification der Wein-Sorten nach ihre beeren. Meissen. 171.

Hammer, O., Harper, D.A.T., and Ryan, P.D. (2001). Past: paleontological Statistics software package for education and data analysis. Paleontologia Electronica, 4(1): 9.

Hurtado, M., Vilanova, S., Plazas, M., Gramazio, P., Herraiz, F.J., Andújar, I., and Prohens, J. (2013). Phenomics of fruit shape in eggplant (Solanum melongena L.) using Tomato Analyzer software. Scientia Horticulturae, 164: 625-632.

Intrieri, C., Poni, S., Lia, G., and Del Campo, M.G. (2001). Vine performance and leaf physiology of conventionally and minimally pruned Sangiovese grapevines. Vitis, 40(3): 123-130.

Kircherer, A., Roscher, R., Herzog, K-., Simon, S., Förstner, W., and Töpfer, R. (2013). BAT (Berry Analysis Tool): a high-throughput image interpretation tool to acquire the number, diameter, and volume of grapevine berries. Vitis, 52(3): 129-135.

Maia, S.H.Z, Mangolin, C.A., Collet, S.A.O., and Machado, M.F.P.S. (2009). Genetic diversity in somatic mutants of grape (Vitis vinifera) cultivar Italia based on random amplified polymorphic DNA. Genetics and Molecular Research, 8(1): 28-38.

Miller, P. (1724). The gardeners and florists dictionary: of a complete system of horticulture containing. London. 501.

OIV (2009). OIV descriptor list for grape varieties and Vitis species, 2nd ed. Office International de la Vigne et du Vin, Paris, France.

Parkinson, J. (1629). Paradisi in sole paradisus terrestris.Humfrey Lownes and Robert Young, London, p. 650.

Predieri, S., Dris, R., and Rapparini, F. (2004). Influence of growing conditions on yield and quality of cherry: II. Fruit quality. Food, Agriculture \& Environment, 2(1): 307-309.

Rodríguez, G., Strecker, J., Brewer, M., Gonzalo, M. J., Anderson, C., Lang, L., Sullivan, D., Wagner, E., Strecker, B., Drushal, R., Dujmovic, N., Fujimuro, K., Jack,A., Njanji, I., Thomas, J., Gray, S., and van der Knaap, E. (2010). Tomato analyzer user manual version 3.

Roscher, R., Herzog, K., Kunkel, A., Kicherer, A., Töpfer, R., and Förstner, W. (2014). Automated image analysis framework for high-throughput determination of grapevine berry sizes using conditional random fields. Computers and Electronics in Agriculture, 100: 148-158.

Royo, C., Torres-Pérez, R., and Carbonell-Bejerano, P. (2018). The major origin of seedless grapes is associated with a missense mutation in the MADS-box gene VviAGL11. Plant Physiology, 177: 1234-1253.

Sabir, A. (2011). Influences of self- and cross-pollinations on berry set, seed characteristics and germination progress of grape (Vitis vinifera cv. Italia). International Journal of Agriculture and Biology, 13(4): 591-594.

Szikszai, F.B. (1590). Nomenclatura seu dictionarium Latino Ungaricum per clarissimum virum D. Basilium Fabricium Szikszavianum, Debrecini.

Open Access. This is an open-access article distributed under the terms of the Creative Commons Attribution 4.0 International License (https://creativecommons.org/licenses/by/4.0/), which permits unrestricted use, distribution, and reproduction in any medium, provided the original author and source are credited, a link to the CC License is provided, and changes - if any - are indicated. (SID_1) 